\title{
The role of grandparents of children with cancer in the hospital
}

\author{
O papel dos avós de crianças com câncer hospitalizadas \\ El papel de los abuelos de niños com cáncer hospitalizados
}

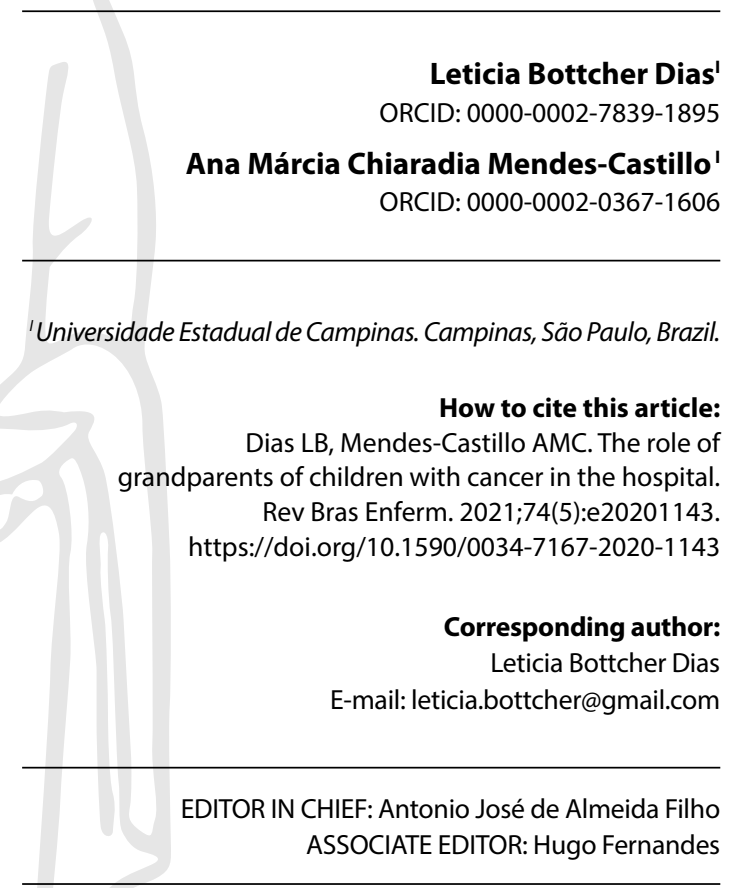

Submission: $10-05-2020$
Approval: 02-05-2021

\begin{abstract}
Objective: To understand the role of grandparents of hospitalized children with cancer. Methods: In a qualitative study, we interviewed eleven grandparents of children with cancer hospitalized at a referral center for pediatric oncology in São Paulo. The data were analyzed using the Hybrid Framework of Thematic Analysis. Results: Six themes were found to describe the role of grandparents in this context: Being the family's support, Sharing love to my child and my grandchild, Being there for my child and my grandchild, Offering spiritual support to my child and my grandchild, Making an effort to be able to manage my own feelings and Balancing the demands of hospitalization with available resources. Final considerations: The findings show the significance of the grandparents' role in this experience and emphasize the value of being considered, by health professionals, as part of the family and care. Descriptors: Child; Family Relations; Role Playing; Grandparents; Neoplasms.
\end{abstract}

\section{RESUMO}

Objetivo: Compreender o papel dos avós de crianças com câncer hospitalizadas. Métodos: Estudo qualitativo, no qual foram entrevistados onze avós de crianças com câncer hospitalizadas em um centro de referência em oncologia pediátrica no interior de São Paulo. Os dados foram analisados a partir do Modelo Híbrido de Análise Temática. Resultados: Foram encontrados seis temas para descrever a função dos avós nesse contexto: Ser o alicerce da família, Transmitir amor para o meu filho e meu neto, Estar presente para o meu filho e o meu neto, Oferecer suporte espiritual para o meu filho e o meu neto, Lutar para conseguir manejar os próprios sentimentos e Equilibrar as demandas da hospitalização com os recursos disponíveis. Considerações finais: Os dados evidenciam a relevância do papel dos avós nessa experiência e ressaltam a importância de serem considerados, pelos profissionais da saúde, como parte da família e do cuidado. Descritores: Criança; Relações Familiares; Desempenho de Papéis; Avós; Neoplasias.

\section{RESUMEN}

Objetivo: Comprender el papel de los abuelos de niños con cáncer hospitalizados. Métodos: Estudio cualitativo en el que fueron entrevistados once abuelos de niños hospitalizados en un centro de referencia en oncología pediátrica del interior de São Paulo. Datos analizados a partir del Modelo Híbrido de Análisis Temático. Resultados: Fueron encontrados seis temas para describir la función de los abuelos en este contexto: Ser el puntal de la familia; Transmitir amor a mi hijo y a mi nieto; Estar presente para mi hijo y para mi nieto; Brindar soporte espiritual para mi hijo y para mi nieto; Luchar por conseguir manejar los propios sentimientos; $y$ Equilibrar las demandas de la internación con los recursos disponibles. Consideraciones finales: Los datos evidencian la relevancia del papel de los abuelos en esta experiencia y destacan la importancia de que sean considerados parte de la familia y del cuidado por los profesionales de salud.

Descriptores: Niño; Relaciones Familiares; Desempeño de Papel; Abuelos; Neoplasias. 


\section{INTRODUCTION}

In recent decades, the population pyramid in Brazil has been inverting, as the number of elderly people has increased, due to the increase in life expectancy. Thus, there is the possibility of greater interaction between generations and living the role of grandparents for a longer time and with greater participation within the family ${ }^{(1)}$.

Becoming a grandmother is one of the main milestones of transition to the late-life course and tends to overlap with retirement, the decline in economic conditions and, lately, care for the elderly parents themselves ${ }^{(2)}$. The birth of a grandchild is described, by maternal grandmothers, as a wonderful and longawaited moment, which reminds of the birth of their children. Grandmothers describe it as a memory movie and feel that they can be more loving and spend more time with their grandchildren than they were and spent with their children ${ }^{(3)}$.

In contemporary society, grandparents play more active roles, taking care of their grandchildren directly, enabling parents to have professional, personal, and entertaining activities ${ }^{(3-4)}$. Studies have already pointed out the importance of support and the presence of grandparents in circumstances such as adolescent motherhood, divorce and remarriage of children, illnesses of grandchildren and the death of a family member ${ }^{(1-4)}$.

The impact that a serious illness of the grandchild, such as pediatric cancer, causes on grandparents has gained visibility, having been described as the worst experience of their life $\mathrm{e}^{(5)}$. The grandparents of children with cancer have lower physical and psychological health, report more pain, anxiety and depression, consider their health worse, have more difficulty sleeping and show more tension with their partners when compared to grandparents of healthy children ${ }^{(6)}$.

Even in the face of their own suffering, grandparents seek to meet the needs of the child's family, even if, for this, they must restrain their own demands. Since diagnosis, grandparents are an important source of emotional support and believe that they need to be strong to care for their children and grandchildren. These grandparents are giving support and seek strength to be always available, even if it is challenging to them ${ }^{(7-8)}$.

Given this scenario, in which we see, on the one hand, the suffering of grandparents being little considered and, on the other hand, all the support they offer to the family, the question that stimulated this study was: "What is the role of the grandparents when their grandchild has cancer and is hospitalized?". With the term "role", we seek to access the active role that grandparents play in the context of hospitalization of their grandchild under cancer treatment $^{(9)}$. Herewith, we hope to access a dimension still little explored in the literature, about the experience of these family members who are increasingly present in situations of children's illness, to guide professionals to think about appropriate interventions.

\section{OBJECTIVE}

This study aims to understand the role of grandparents of hospitalized children with cancer.

\section{METHODS}

\section{Ethical aspects}

The ethical aspects of the research, according to Resolution CNS 466/2012, were strictly respected, with data collection starting only after approval by the Ethics Committee of the local study hospital. The project was approved in 2018 and 2019. The Informed Consent Form was applied. In the text, the names of the participants were encoded to guarantee privacy.

By working at the institution at the time of data collection, the author of the work strived to minimize the impacts during the interview, performing a self-reflective practice and avoiding using potential previous information about the family of the participating grandparent. To avoid the researcher's involuntary influence, the interviews and the results were discussed with another researcher, contributing to the quality and rigor of the investigation $^{(10)}$. Moreover, the Consolidated Criteria for Qualitative Research Reporting tool (COREQ) was used to describe and verify the research team, the project and the data analysis ${ }^{(11)}$.

\section{Study type}

This is a qualitative study, based on the Hybrid Thematic Analysis framework $^{(12)}$ as a method of data analysis. This framework has been increasingly used in nursing research, using both deductive analyses, guided by a template or a theoretical model, and inductive analysis, guided by data, allowing the combination of the theoretical model with the new themes that arise ${ }^{(12)}$.

For the template or theoretical model, we adopted the Good Parent Tool ${ }^{(13)}$. This model was created from studies that found that, when a child is in end-of-life care, one of the main factors that influence the parents' decision on how good parents would decide ${ }^{(14-15)}$. The feeling of having fulfilled this role, of good parents, emotionally helps parents to go through experiences such as mourning. So, understanding what it means to be a good father for child a with cancer can guide care, optimizing support in difficult decisions and making parents more comfortable to make their decisions as good parents ${ }^{(13-14)}$.

From this, a study to define the good parent was carried out with 62 parents of children with cancer and who made decisions at the end of their lives. The definition gave rise to the Good Parent Tool $^{(13)}$, composed of eight themes: doing right by my child, being there for my child, conveying love to my child, being a good life example, being an advocate for my child, letting the lord lead, not allowing suffering and making my child healthy ${ }^{(13)}$. In this tool, the definition of "being good" is closely related to the role played. The Tool has already been used in other contexts, such as, for example, in the description of the good patient from the perspective of adolescents with cancer ${ }^{(16)}$.

\section{Population, scenario, and data collection}

The study scenario was a hospital specialized in childhood cancer in the interior of the state of São Paulo. Data collection was carried out between August 2018 and January 2019, through 
semi-structured interviews, using the guiding question "Tell me how your experience of having a grandchild with cancer has been", followed by questions elaborated a from the Good Parent Tool ${ }^{(13)}$ : "Tell me about a situation where you think you did something good for your grandchild after his/her illness.", "Where do you find support to go through this experience?" and "Here inside the hospital, how can I help you to be the best grandparent possible for your grandchild?"The interviews totaled 251 minutes of audio, with an average duration of 35 minutes.

The study participants were 11 grandparents of children with cancer. Of this total, 9 were grandmothers and 2 were grandfathers, the majority $(n=9)$ maternal, and all had frequent contact with the child, both before he or she became ill and during hospitalization.

\section{Selection criteria}

The grandparents were contacted after the indication of professionals from the institution to participate. The following factors were considered as inclusion criteria: being the grandparents of children undergoing cancer treatment, admitted to any unit of the hospital, who considered themselves close and participating in the family of the child who became ill and who visited or were together with the child's parents in the hospital. As exclusion criteria, grandparents who had custody of their grandchildren were considered.

\section{Data analysis and treatment}

Data analysis, using the Hybrid Thematic Analysis Framework ${ }^{(12),}$ recognizes patterns within the data through the inductive approach, guided by the data, and the deductive one, guided by a model. This model, or template, works as a tool, enabling the relationship with the theoretical framework ${ }^{(12)}$.

After transcribing the interviews, in vivo codes were generated. These are units of meaning that help with the organization and identification of patterns, enabling data analysis and generating the initial themes. These codes underwent a preliminary analysis, called inductive coding, which grouped them ${ }^{(12)}$.

Analyzing the interviews again, the template was applied to verify the similarity of the data. Similar data were kept with the same name as the template for the structure of the results ${ }^{(12)}$.

After the inductive and deductive analyzes, the codes were grouped by the similarity process, with their connections and conceptual differences, increasing the level of abstraction and creating themes that show the role of grandparents. The themes were validated with the template, keeping the original name when possible and being described to clarify and confirm the direction taken for the classification of themes ${ }^{(12)}$.

The data collection stopped when no new properties and dimensions appeared in the data ${ }^{(12)}$.

\section{RESULTS}

The process of deductive and inductive data analysis allowed organizing the role of the grandparent during the hospitalized grandchild with cancer into six themes: Being the family's support, Sharing love to my child and my grandchild, Being there for my child and my grandchild, Offering spiritual support to my child and my grandchild, Making an effort to be able to manage my own feelings and Balancing the demands of hospitalization with available resources.

The diagnosis deeply worries the grandparents and ends up forcing them to rearrange all their activities and involvement in the family. Suffering becomes frequent in their lives, for the fear of death of their grandchild all the time. "My grandson, with cancer" is a horrifying statement that echoes within them, making them face a difficult reality, full of suffering and uncertainty.

In being the family's support grandparents believe that it is their role to provide much of the assistance and necessary support, however, they believe that this support needs to happen without them appearing, that is, allowing the adult son/daughter to take over the role of care. As a foundation, they support the family, but are practically invisible.

I always try to help, just to be here [in the companion's room] and to know that she [daughter] is there and is fine, I'm taking care of them [...] all the time we talk through the glass, I see them from the outside. (Priscilla)

Just like a foundation, grandparents make it possible for the house straight, to keep up with the routines and the life not to collapse completely because of cancer. However, just as an earthquake or a windstorm hits a house, the illness of a child affects the whole family and, when providing the necessary support, grandparents suffer from the tremble of this event, even when they do not show it.

Sharing love to my child and my grandchild is another theme that has emerged as a role inherent to the grandparents. In the relationship with the adult child, sharing love is crucial in the disease and the grandparents do it crying and sharing the suffering, sharing a tender love that nurtures the child.

I just wanted to hug my daughter and say that, oh, we're here, we're together. And that was it. The doctor said: look, I will leave you. And we hugged and she would cry. (Edith)

Regarding the relationship with the grandchild, since they found out about the disease, the grandparent already shares this love, aiming to help the grandchild to face the difficult experience of cancer. At the hospital, grandparents offer affection and warmth to their grandchildren, trying to minimize their pain with messages and words of comfort. They attend to their wishes, buying food and toys, but believe that their role goes beyond giving things, as it involves giving in love.

Grandparents describe the continuous need to show love by playing with grandchildren in the hospital. When present, they insist on playing with their grandchildren. When they are not, these grandparents worry about having someone who is dedicated to playing with the child.

I pick him up [grandson], put him in that IV thing and go out playing around the corridors. I make a lot of fun because I don't let him stand, I don't let him be sad. (Carol)

Being there for my child and my grandchild is a need for grandparents during all stages of their grandchildren's illness, regardless of the challenges and sacrifices that will eventually be imposed 
for this. With that, they insist on always knowing what their child and the grandchild are experiencing, accompany in person whenever possible or, even make themselves present through communication technologies.

I go in all consultations together; only two that I was in my city and I couldn't go [...] But every time I was making a video call to see how he was doing. (Carol)

Often, being present requires sacrifices on the part of grandparents, of previous plans, work, as well as abandoning the rest of the family and any other chores. Believing that their children feel more secure with their presence, they spare no effort to be there. Grandparents readily offer themselves to take turns with their children to be a companion for the grandchildren, since they see their child's tiredness and offer to support rest and, at the same time, to be closer to the grandchild. They believe that they are the trustworthy people with whom their children can leave their grandchildren, to rest or even leave the hospital for a period.

It was 3 am and she came to the room. I said: no, daughter, you can sleep; if he cries too much, I will call you. Then she slept, right. She was tired. (Priscilla)

Offering spiritual support to my child and my grandchild is a role of grandparents, which happens because they believe in a superior being who can provide care, comfort, and healing. They feel they should ask for blessings for their grandchildren. It is important to highlight that grandparents do this not only for their grandchildren, but for the other hospitalized children with whom they have contact and for whom they feel sorry.

When hospitalization is necessary, grandparents use groups of electronic messages, from different circles of social interaction, friends, and distant family members, asking for prayers for their grandchildren and believing that blessings will come, in different ways and by different beliefs. Grandparents transcend their own religion to ask for their grandchildren's healing and health.

When she is hospitalized, Ijoin the groups and send messages. Then, the city, all the people, start to pray. These days I had 400 people, at $3 \mathrm{pm}$, all praying for her over there with my sister. (Silmara)

They encourage the child and grandchild's faith. Since the diagnosis and in times of suffering, grandparents bring their children closer to religious figures and tell their grandchildren about God and the godly power to control everything and to heal.

I can show her that, even with the pain, she still has God. I say that the heavenly father is with her, minimizing her pain, which will soon go away. (Liz)

All this suffering does not come without an emotional burden for grandparents. So, they make an effort to be able to manage their own feelings and do everything on their own, as they believe that they should not overload other family members with their own demands, especially the adult children, whose son/daughter is sick.

A combination of tolerance and fear of stumbling takes over the grandparents. Throughout the treatment, they find themselves struggling to understand what is happening, afraid to ask and be ignored or fail to understand. Even though grandparents believe that they do not have the strength to bear the experience, as time goes on, they find strength in facing each moment as a message.

I am unsteady [...] Every day, a victory, every day, a lesson. Yes, you believe, you end up believing that you really have that strength. (Edith)

The experience of having a grandchild with cancer is devastating. I cannot deny the desire not to be going through this, but since this is not an option, grandparents see the disease as an opportunity to learn and improve their and their child's persona, making learning one of the ways to manage the feelings triggered by the disease.

I promised God that I would try to live every minute, that I would enjoy my family, that I will learn to love myself, the way I am, accept myself the way l am. (Carol)

To go through this experience, grandparents also need to balance the demands of hospitalization with the available resources. Grandparents point to difficulties related to their health, their limitations, and the complicated relationship with health professionals.

Due to the natural and physiological process of aging, grandparents face their health as an important limitation in the performance of their role. Besides physical symptoms, the grandparents report being very anxious in the hospital, on top of believing that they will certainly have other health problems after the treatment of their grandchildren ends.

I try not to get sick, not even the flu, not a cough. If I see that my sinus is coming, I take acetylcysteine. I manage it myself; I try to restore myself to stay with her, the 15 days, whatever happens. (Silmara)

Furthermore, when the grandparents have some professional activity, a new limitation arises, linked to the difficulty in being on leave from work, requesting leave, or asking for a vacation.

Grandparents have trouble understanding what is happening, saying that the language used is a barrier to understand and be able to help their grandchildren even more. The bad news is communicated coldly by professionals as if it were routine and natural, which increases anguish and suffering. The divergence of information among professionals also makes grandparents uncomfortable and suspicious, as we see in Liz's statement:

Then, they performed the third US [Ultrasound] and she had liquid in the lung. At the second time, he had already said everything was set to drain. He even marked where it was. But then, the other doctors said no, that it was not enough to drain. Then, a week later, what happened? Bruna needed to drain the lung and lost $6 \%$ of it. (Liz)

In this environment of skepticism, the cold and distant attitude of some professionals increases dissatisfaction and may even make grandparents think that their grandchildren are being treated differently because of possible complaints about the care offered.

However, while professionals can be a limitation, they can also be an important resource for grandparents to strengthen 
themselves to face this experience. Grandparents consider communication with professionals to be very important. They say that many of them want to talk to them, not devaluing them for being grandparents. They speak of friendship made with professionals outside the hospital walls, including going for a walk and talking.

The grandparents say that some professionals show affection to them and their grandchildren, which makes them feel relieved and makes them feel safe.

I went to the ICU these days. Then, the Japanese doctor came in and my grandson wanted Mommy, and he was crying. Then the doctor sang, and he stopped crying. He said: if you want, I will sing, will you smile or cry? And he stopped crying while he was talking. (Roberto)

Other than the professionals who take care of the grandchild, grandparents also consider family, friends inside and outside the hospital and the structure offered by the treatment center as important resources.

Because of the need to spend most of their time near the hospital, grandparents say that the structure offered by the hospital is extremely important for them, the parents, and the child to be able to be there. They talk about the support house where they can stay throughout the treatment, which is, other than a roof, a place where they meet other families and get stronger because of the support received.

So, I said, I play with him, if it weren't for situation. Because you bathe, have a clean bed, a full tummy, every food they ask for, they bring, there is a television, what do you want? Toys the whole time. I wouldn't want to leave (the hospital). (Carol)

Therefore, making use of resources, to balance the demands, helps grandparents to accomplish what they believe they must do to be good grandparents, playing an active role in the context of hospitalization of grandchildren with cancer.

\section{DISCUSSION}

The findings hereby show the suffering of grandparents who have a grandchild with cancer, corroborating growing scientific evidence that points to this same reality ${ }^{(1,7-8,17-18)}$. The literature points out that grandparents are key elements of the parents' support network, being often the first and main choice, as this study also points out ${ }^{(19)}$.

The Good Parent Tool ${ }^{(13)}$ proved to be a useful tool, as it defines important characteristics that compose what parents believe to be inherent in their role as good parents. The concept of "being good" means that the person has the expected qualities, is competent in his duties and brings advantages, helping and benefiting others ${ }^{(13)}$. In this sense, being good is closely related to the individual's ability to play his/her role effectively. Thus, we can assume that the themes found in this study propose the attributes that compose the role of a good grandparent of the child with cancer, since they describe the perspectives that the participants themselves have about their role.

The function of giving support without being in the leading role, represented by the theme "being the family's support", increases the responsibility of grandparents, requiring sensitivity and proactivity ${ }^{(18,20)}$. A study aimed at understanding, from the perspective of grandparents, the experience of having a grandchild hospitalized in a pediatric ICU, found that grandparents recognize that they are not the primary caregivers, but give support so that their children can manage the situation, and avoid conflicts related to each one's role. These grandparents are compared to an anchor who, amid the storm, will make whatever effort is necessary to ensure that the boat, which is compared to the family, is safe. When they are giving support, grandparents play roles that can be caring for a healthy sibling, staying in the hospital, or performing activities that allow parents to be in the hospital(20).

Due to their role, the rates of depression and health problems caused by suffering are higher in this population ${ }^{(6)}$. Our study provides alarming data that indicate that, even amid wear and tear, grandparents are still struggling and try not to fade in the face of weaknesses, as they believe they need to be there for their child and grandchild.

When we think of families and grandparents, intervening is helping grandparents to create new ways of interacting with the family and, with these interactions, achieve the role of a good grandparent for the child with cancer ${ }^{(9,13)}$. Grandparents struggle to manage their own feelings and balance demands with resources. Especially in this scenario, such themes should be the target of nursing interventions.

When experiencing stressful situations in the hospital, professionals can identify, in the grandparents, behaviors that result from the experience and praise them, reinforcing and making compliments to the grandparents for learning from the situation. Furthermore, professionals can assist, validating or normalizing the emotional responses of grandparents, as these responses are often hidden ${ }^{(9)}$.

Another limitation that needs to be highlighted is that of the grandparents' health. This work goes through child health care and integrates health care for the elderly. In this study, two moments are targets of this medicalization: the need to always be well to help the parents and to know that after the end of the treatment these grandparents will have some physical or mental sequelae as well(6).

Upon grandchildren's hospitalization, grandparents may forget to take their medication, demand too much of their physical strength, when standing next to their grandchild, and have a poor diet. Professionals should know the grandparents and recognize their needs, reminding them of their health conditions, providing them with a comfortable physical area and encouraging them to eat, to make them feel safe that professionals will care for the child when they are not around.

The bond between the professional and the grandparents takes place because of the presence of the grandparents in prolonged hospitalizations. This bond makes the professional be more in touch, which causes greater suffering in the face of the child's worsening condition or death.

A study described the strategies that professionals working in pediatric oncology use to stay in a job that involves great suffering. They are surrounded by helplessness and point out the need for support from colleagues, leisure activities, psychological and spiritual support and keeping distance from patients and families as factors that contribute to minimizing their suffering ${ }^{(21)}$. 
Therefore, to exercise the support that grandparents need, professionals working with pediatric oncology also need to be supported. A study with nursing professionals in an intensive care unit showed that $79.17 \%$ of them have work-related exhaustion symptoms and suffering ${ }^{(22)}$. Hospital institutions must be aware of the mental health of employees ${ }^{(21-22)}$.

Grandparents are already known for their affection, love, and dedication to their grandchildren. Amid the suffering of childhood cancer, sharing love is an important role of grandparents, and this love is shared not only to the grandchild, but also to the child. This strengthens the idea that, while the receivers of that love are increased, so is suffering. We can provide moments when grandparents can show affection for their grandchildren, allowing them to play and bring toys, and can show affection for their children, to provide moments when they can be together, sharing their feelings and problems.

In parallel with sharing love, being there for my child and my grandchild was another theme that came up in line with other highlights of international literature ${ }^{(8,18)}$. The inclusion of parents in the care of hospitalized children has been extensively studied and has been consistently followed by childcare institutions. The benefits that grandparents bring to the family are also being shown currently. A study aimed at updating and expanding the perception of mothers of children with disabilities about the support of their grandparents, found that most of the provision of this support was related to face-to-face contact and closeness ${ }^{(23)}$. Such research, in line with this study, reinforces the need for health professionals to favor the active involvement of grandparents. It is necessary to think about including and encouraging the grandparents in this context. Professionals must be flexible in allowing grandparents to be present with their child and grandchild, since both are targets of the grandparent's role, and the strict hospital routine distances them and makes this relationship more complicated ${ }^{(20)}$.

The elderly already seek, in the spiritual component, well-being and support for difficulties ${ }^{(24)}$. The combination of religious and spiritual elements in health care offers a more effective response to the suffering of families ${ }^{(25)}$.

Nurses must provide spiritual support to their patients and family. When using active listening, the nurse already begins spiritual care. Participating in prayers with the family can promote well-being and favor the professional-family bonding process ${ }^{(26)}$. This type of intervention not only helps grandparents to achieve their role, to offer this spiritual support, but also helps them to see this support reaching their child and grandchild, also, through the health team.

The findings of the present study also point out the grandparents' difficulty in understanding what is being said by the professionals. This is because of two aspects: the language used and the lack of communication and deal between professionals. As for communication flaws, there are differences in the speech of professionals from the same institution, whether about treatment or institutional routines ${ }^{(27)}$.

This communication issue catches our attention to the need for team discussions, so that nurses, on-duty doctors, surgeons, doctors who report exams, physiotherapists and other professionals have consistency in speech, not only with grandparents, but with the family. The professionals who take care of the child must know the proposed care plan, so they can carry out their actions and inform the family without any misunderstandings, ensuring the mutual comprehension of all those involved.

The promotion of support programs for grandparents has already been the target of investments in other countries. These programs aim to reduce anxiety and help grandparents to live with sick grandchildren ${ }^{(1)}$. Brazilian strategies need to be created to assist grandparents and make them play their role with support, lessening later complications.

The characteristics of the Good Parent Tool ${ }^{(13)}$ that were not described in this study concerning the role of grandparents support the idea of the diversity of roles. This demonstrates the need to think of grandparents as distinct figures, with well-defined tasks and roles, which play an important function in the family context.

\section{Study limitations}

As a study limitation, it is worth mentioning the difficulty in identifying potential participants, due to the dynamics of visits and physical structure of the institution, which isolates other companions and visits from the room where the child is. Thus, nursing professionals sometimes had difficulties in finding the grandparents who would usually be at the hospital.

\section{Contributions to the area}

As for recommendations for practice, it is necessary to reflect on changing rules and routines, favoring the relationship of grandparents with the child and grandchild in the hospital, but also in the relationship of professionals and grandparents in the routine of the hospital environment. Furthermore, we can suggest the creation of strategies to meet the demand of grandparents, either with national booklets, either with personal groups or through technologies.

Professionals must be aware of the best way to access the grandparents who are present in their routines and propose changes, besides using the interventions, explained here, in their practice. Professionals from different places who care for children with cancer can come together to encourage the creation of online groups that share experiences and provide guidance.

\section{FINAL CONSIDERATIONS}

This research allowed us to understand the role of grandparents when grandchildren have cancer. We understand that this role is performed in a context permeated with great suffering. Therefore, their roles also occur in a magnified way, that is, they involve relationships with the child, the grandchild, and the whole family.

Grandparents consider it to be their role to support their children's family as a foundation. We need to be aware of the support conditions of this foundation upon a cancer diagnosis in the grandchildren, because, for them to be present, share love and offer spiritual support, grandparents need to manage their feelings and balance the demands. The presence and assistance of professionals at these times are essential for these family members to play the role of good grandparents.

In this scenario, we still have a long way to advance in the strategies that consider the family as a caring entity. 


\section{REFERENCES}

1. Mendes-Castillo AMC, Bousso RS. The grandparents of sick children: a new perspective for research with families in Brazil. Rev Min Enferm. 2015;19(3):793-6. https://doi.org/10.1590/s1980-220x2017040003395

2. Moreira LVC, Rabinovich EP. Dias CMSB, (Org.). A voz dos avós: família e sociedade. Curitiba: CRV; 2017

3. Kipper CDR, Lopes RS. Becoming a grandmother in the individuation process. Psicol Teor Pesqui. 2006;22(1):29-34. https://doi.org/10.1590/ S0102-37722006000100004

4. Zamberletti J, Cavrini G, Tomassini C. Grandparents providing childcare in Italy. European J Ageing. 2018;15:265-75. https://doi.org/10.1007/ s10433-018-0479-y

5. Charlebois S, Bouchard L. "The worse experience": the experiences of grandparents who have a grandchild with cancer. Canadian Oncol Nurs J [Internet]. 2007 [cited 2019 Sep 13];17(1):26-36. Available from: https://www.ncbi.nlm.nih.gov/pubmed/17847987

6. Wakefield CE, Fardell JE, Doolan EL, Drew D, Lourenco RDA, Young AL, et al. Grandparents of children with cancer: Quality of life, medication and hospitalizations. Pediatr Blood Cancer. 2017;64:163-71. https://doi.org/10.1002/pbc.26153

7. Moules NJ, McCaffrey G, Laing CM, Tapp DM, Strother D. Grandparents' experiences of childhood cancer, part 1. J Pediatric Oncol Nurs. 2012;29:119-31. https://doi.org/10.1177/1043454212439626

8. Moules NJ, McCaffrey G, Laing CM, Tapp DM, Strother D. Grandparents' experiences of childhood cancer, part 2: The need for support. J Pediatric Oncol Nurs. 2012;29:133-40. https://doi.org/10.1177/1043454212439627

9. Wright LM, Leahey M. Enfermeiras e famílias: um guia para avaliação e intervenção na família. 5a ed. São Paulo: Roca; 2015.

10. Sposito AMP, Silva-Rodrigues FM, Sparapani VC, Pfeofer LI, Lima RAG, Nascimento LC. Coping Strategies Used by Hospitalized Children With Cancer Undergoing Chemotherapy. J Nurs Scholarship. 2015;47. https://doi.org/10.1111/jnu.12126

11. Tong A, Sainsbury P, Craig J. Consolidated criteria for reporting qualitative research (COREQ): a 32-item checklist for interviews and focus groups. Int J Qual Health Care. 2007;19(6):349-57. https://doi.org/10.1093/intqhc/mzm042

12. Fereday J, Muir-Cochrane E. Demonstrating rigor using thematic analysis: a hybrid approach of inductive and deductive coding and theme development. Int J Qualit Methods 2006;5(1):1-11. https://doi.org/10.1177/160940690600500107

13. Hinds PS, Oakes LL, Hicks J, Powell B, Srivastava DK, Harper SLS, et al. "Trying to be a good parent" as defined by interviews with parents Who made phase I, terminal care, and resuscitation decisions for their children. J Clin Oncol. 2009;27:5979-85. https://doi.org/10.1200/JCO.2008.20.0204

14. Hinds PS, Oakes L, Furman W, Quargnenti A, Olson MS, Foppiano P, et al. End-of-Life Decision Making by Adolescents, Parents and Healthcare Providers in Pediatric Oncology. Cancer Nurs. [Internet]. 2001 [cited 2019 Sep 13];24(2):122-36. Available from: https://www.ncbi. nlm.nih.gov/pubmed/11318260

15. Hinds PS, Drew D, Oakes LL, Fouladi M, Spunt SL, Church C, et al. End-of-Life Care Preferences of Pediatric Patients With Cancer. J Clin Oncol. 2005;23(36):9146-54. https://doi.org/10.1200/JCO.2005.10.538

16. Weaver MS, Baker JN, Gattuso JS, Gibson DV, Hinds PM. "Being a Good Patient" during times of illness as defined by adolescent patients with cancer. Cancer. 2016;122:2224-33. https://doi.org/10.1002/cncr.30033

17. Mendes-Castillo AMC, Bousso RS. The experience of grandmothers of children with câncer. Rev Bras Enferm. 2016;69(3):559-65. https://doi. org/10.1590/0034-7167.2016690320i

18. Wakefield CE, Drew D, Ellis SJ, Doolan EL, McLoonde JK, Cohn RJ. Grandparents of children with cancer: a controlled study of distress, support, and barriers to care. Psychooncol. 2014;23(8):855-61. https://doi.org/10.1002/pon.3513

19. Morais RCM, Souza TV, Oliveira ICS, Moraes JRMM. Strutucture oh the social network of mothers/caregivers of hospitalized children. Cogitare Enferm. 2018;1(23):e50456. https://doi.org/10.5380/ce.v23i1.50456

20. Moraes ES, Mendes-Castillo AMC. The experience of grandparents of children hospitalized in Pediatric Intensive Care Unit. Rev Esc Enferm USP. 2018;52:e03395. https://doi.org/10.1590/S1980-220X2017040003395

21. Bubolz BK, Barboza MCN, Amaral DED, Bernardes LS, Muniz RM. Perceptions of nursing professionals with regards to the suffering and its coping strategies in oncology. Rev Pesqui: Cuid Fundam. 2019;11(3):599-606. https://doi.org/10.9789/2175-5361.2019.v11i2.599-606

22. Santos EM, França IJS, Boas LLV, Miranda AP. Health of workers in the hospital environment: risk factors for burnout syndrome. Rev Nurs [Internet]. 2018 [cited 2019 Sep 13];22(248):2509-13. Available from: http://www.revistanursing.com.br/revistas/248/pg24.pdf

23. Crettendena A, Lamb J, Densonb L. Grandparent support of mothers caring for a child with a disability: Impacts for maternal mental health. Res Develop Disabil. 2018;76:35-45. https://doi.org/10.1016/j.ridd.2018.02.004

24. Garces SBB, Figueiró MF, Hansen D, Rosa CB, Brunelli AV, Bianchi PD, et al. Resiliência entre mulheres idosas e sua associação com o bemestar espiritual e o apoio social. Estud Interdiscipl Envelhec [Internet] 2017 [cited 2019 Sep 13];22(1):9-30. Available from: https://seer.ufrgs. br/RevEnvelhecer/article/view/43412/48373

25. Proserpio T, Ferrari A, Veneroni L, Arice C, Massimino M, Clerici CA. Cooperation between in-hospital psychological support and pastoral care providers: obstacles and opportunities for a modern approach. Tumori J. 2018;104(4):243-51. https://doi.org/10.5301/tj.5000676 
26. Santos EL, Navarine TCRR, Costa MML. The Elderly and Spirituality: considerations for holistic nursing care. Rev Nurs [Internet]. 2018 [cited 2019 Sep 13];21(244):2342-44. Available from: http://www.revistanursing.com.br/revistas/244-Setembro2018/O_idoso_espiritualidade.pdf

27. Silva LMA, Souza VMVB. Therapeutic communication: challenges for dialogue in a Brazilian children's hospital. Reciis Rev Eletron Comun Inf Inov Saúde. 2018;12(2):134-47. https://doi.org/10.29397/reciis.v12i2.1372 